\title{
Analysis of Investments
}

\author{
J Pavithra, Anish . S, K. Premalatha
}

\begin{abstract}
The investigation is an examination of speculation conduct of individual speculators of securities exchange to enquire whether there is any effect of three autonomous factors to be specific Demographic Factors, Awareness and Perceived Risk Attitude on just a single ward variable Investment Behavior. The investigation has gathered essential information from 400 arbitrarily chose individual financial specialists of securities exchange from different regions of West Bengal utilizing an organized poll on five point Likert scale. The investigation finds that the mindfulness levels of the individual speculators are on moderate level and money related mindfulness is more than social learning. Seen Risk Attitude is primarily guided by Affect instead of Cognition. The investigation show that Demographic Factors, Awareness and Perceived Risk Attitude altogether impact Investment Behavior of individual speculators of financial exchange.

Keywords: Stock Market, Behavioural Finance, Perceived Risk Attitude
\end{abstract}

\section{INTRODUCTION}

Venture is the dedication of present period and furthermore the desire for return or the advantage for such responsibility in future. There is in every case some hazard associated with deference of return and rule sum contributed[1],[3],[5].

Thus investing pattern based on the above investment processes will yield ample profit and minimize risk.

Investors tend to look at risk, return and liquidity characteristics while deciding on their individual preference pattern of investment. Each financial assets will have a certain level of these characteristics. These, in some way determine the type of financial asset[2],[4],[6].

Based on the preferred risk, return and liquidity each investors select an investment that his investment objective.

\section{A. Need For the Study}

It is observed from the present value of the investment made by different type of investment that the value has depleted from their original investment value. There is a generic problem with reference to the behavior and strategy of the investors while investing in different products. It is a common observation that the most of the short term investors who frequently interact with the market lose their investment.
Hence there is a need to study the generic problem associated with the investment pattern of different types of investors in equity and derivative market.

\section{B. Scope of the Study}

- The study will interact with different types of investors depending upon the social, financial and personal status.

- The study covers the various categories of investment opportunities available to the investors based upon their status[7],[9],[11].

- The study covers the investment pattern vis-à-vis different types of investors using various tools and analysis.

- The study to focus the strength and weakness in the approach of the investors while investing in the various products.

- Finally the study will bring out the ways and means to overcome the pitfalls in the investor' $\mathrm{s}$ approach and behavior while investing in different products.

\section{RESEARCH DESIGN}

1. Chi-Square Test

2. Correlation Analysis

\section{A. Statistical Tools}

\section{Chi- square Test}

The chi - square test is used to find out if there any significant relationship between any two variables[8],[10],[12].

\section{A. Chi- square Test: 1}

Chi - square test of independence between opinion on safest return and on mutual funds are better options to protect investments than stock market.

\section{Table -1}

Revised Manuscript Received on July 22, 2019.

Ms. J Pavithra, Department of MBA, Bharath Institute of Higher Education and Research, Chennai, India

Email: pavithralect@yahoo.com

Anish.S, Department of Civil Engineering, Bharath Institute of Higher

Education and Research, Chennai, India.

Email: anishdavidpaul@gmail.com

K. Premalatha, Department of MBA, Bharath Institute of Higher Education and Research, Chennai, India.

Email: premalatha09@gmail.com 


\begin{tabular}{|c|c|c|c|c|c|c|}
\hline $\begin{array}{c}\text { Safest } \\
\text { forms }\end{array}$ & $\begin{array}{c}\text { Stock } \\
\text { market }\end{array}$ & $\begin{array}{c}\text { Mutual } \\
\text { funds }\end{array}$ & $\begin{array}{c}\text { Government } \\
\text { Bonds } \\
\text { Mutua } \\
\text { Funds }\end{array}$ & $\begin{array}{c}\text { Bank } \\
\text { Deposits }\end{array}$ & Commodities & Total \\
\hline $\begin{array}{c}\text { Strongly } \\
\text { Agree }\end{array}$ & 0 & 7 & 0 & 1 & 2 & 10 \\
\hline Agree & 18 & 6 & 4 & 21 & 3 & 52 \\
\hline $\begin{array}{c}\text { Neither } \\
\text { agree } \\
\text { nor } \\
\text { disagree }\end{array}$ & 10 & 2 & 6 & 17 & 2 & 37 \\
\hline $\begin{array}{c}\text { Dis } \\
\text { agree }\end{array}$ & 11 & 2 & 2 & 12 & 0 & 27 \\
\hline $\begin{array}{c}\text { Strongly } \\
\text { disagree }\end{array}$ & 0 & 2 & 3 & 14 & 0 & 19 \\
\hline Total & 39 & 19 & 15 & 65 & 7 & 145 \\
\hline
\end{tabular}

\section{Calculation:}

\section{Hypothesis:}

Null hypothesis $\left(\mathbf{H}_{\mathbf{0}}\right)$ : The attributes are independent. i.e., there is no significant difference between the opinion on safest form of yielding return and opinion on mutual funds are better option to protect investment than stock market[13], [15],[17].

Alternative hypothesis $\left(\mathbf{H}_{1}\right)$ : There is significant difference between the opinions.

The expected frequencies are determined by the formula: $\chi^{2}=\sum\left(\mathrm{O}_{\mathrm{i}}-\mathrm{E}_{\mathrm{i}}\right)^{2} / \mathrm{E}_{\mathrm{i}}$

where;

O- Observed frequency

E- Expected frequency

\begin{tabular}{|c|c|c|c|c|}
\hline 0 & E & O-E & $(\mathrm{O} \mathrm{i}-\mathrm{B} \mathrm{B})^{2}$ & $(\mathrm{O} i-\mathrm{E} i)^{2} / \mathrm{E}$ \\
\hline 0 & 2.69 & -2.69 & 7.2361 & 2.69 \\
\hline 18 & 13.98 & 4.2 & 17.64 & 1.26 \\
\hline 10 & 9.95 & 0.05 & 0.0025 & 0.00025 \\
\hline 11 & 7.26 & 3.74 & 13.98 & 1.98 \\
\hline 0 & 5.1 & -5.1 & 26.01 & 5.1 \\
\hline 7 & 1.3 & 5.7 & 32.49 & 25 \\
\hline 6 & 6.8 & -0.8 & 0.64 & 0.094 \\
\hline 2 & 4.8 & -2.8 & 7.84 & 1.63 \\
\hline 2 & 3.5 & -1.5 & 2.25 & 0.64 \\
\hline 2 & 2.48 & -4.8 & 23.04 & 9.29 \\
\hline 0 & 1.03 & -1.03 & 1.0609 & 1.03 \\
\hline 4 & 5.37 & -1.37 & 1.8769 & 0.34 \\
\hline 6 & 3.8 & 2.2 & 4.84 & 1.27 \\
\hline 2 & 2.7 & -0.7 & 0.49 & 0.18 \\
\hline 3 & 1.96 & 1.04 & 1.081 & 0.55 \\
\hline 1 & 4.48 & -3.48 & 12.11 & 2.70 \\
\hline 21 & 23.3 & -2.3 & 5.29 & 0.22 \\
\hline 17 & 16.58 & 0.42 & 0.176 & 0.010 \\
\hline 12 & 12.10 & -0.10 & 0.10 & 0.0008 \\
\hline 14 & 8.51 & 5.49 & 30.14 & 3.54 \\
\hline 2 & 0.48 & 1.52 & 2.31 & 4.8 \\
\hline 3 & 2.51 & 0.49 & 0.2401 & 0.09 \\
\hline 2 & 1.78 & 0.22 & 0.48 & 0.26 \\
\hline 0 & 1.30 & -1.30 & 1.69 & 1.3 \\
\hline 0 & 0.91 & -0.91 & 0.828 & 0.90 \\
\hline 145 & & & & 64.93 \\
\hline
\end{tabular}

\section{Calculated Value}

The calculated value is 64.94

Tabulated value:

Degree of freedom; $(\mathrm{r}-1) *(\mathrm{c}-1)$

$$
(5-1) \times(5-1)
$$$$
4 \times 4=16
$$

The table value at $5 \%$ level is 26.296

Hence the calculated value 64.93 is greater than the table value,

$\mathrm{H}_{0}$ is rejected and $\mathrm{H}_{1}$ is accepted.

\section{Inference:}

There is a significant difference between the opinion on safest form of yielding return on mutual fund are better option protect investment than stock market.

\section{B. Chi-square Test: 2}

Chi-square test of independence between gender and level of risk willing to take in the investment decisions.

Table -2

\begin{tabular}{|c|c|c|c|c|c|}
\hline $\begin{array}{l}\text { Risk } \\
\text { lev }\end{array}$ & $\begin{array}{l}\text { Very } \\
\text { High } \\
\text { Risk: }\end{array}$ & High Risk & $\begin{array}{l}\text { Average } \\
\text { Risk }\end{array}$ & Low Risk & Total \\
\hline Male & 0 & 40 & 69 & 13 & 122 \\
\hline Female & 0 & 5 & 18 & 0 & 23 \\
\hline Total & 0 & 45 & 87 & 13 & 145 \\
\hline
\end{tabular}

\section{Calculation:}

Hypothesis:

Null hypothesis $\left(\mathbf{H}_{\mathbf{0}}\right)$ : The attributes are independent i.e., there is no significant 
difference between gender and their willingness to take risk.

Alternative hypothesis $\left(\mathbf{H}_{1}\right)$ : There is a significant difference between gender and their willingness to take risk. The expected frequencies are determined by the formula:

Where;

$$
\chi^{2}=\sum(\mathbf{O i}-\mathbf{E i})^{2} / \mathbf{E i}
$$

O- Observed frequency

E-Expected frequency

\begin{tabular}{|c|c|c|c|c|}
\hline 0 & $\mathrm{E}$ & O-E & $\left(\mathrm{O}_{\left.\mathrm{i}-\mathrm{F}_{i} \mathrm{i}\right)}\right.$ & $(\mathrm{O} \mathrm{i}-\mathrm{E}, \mathrm{i})^{2} / \mathrm{E}$ \\
\hline 0 & 0 & 0 & 0 & 0 \\
\hline 0 & 0 & 0 & 0 & 0 \\
\hline 40 & 37.86 & 2.14 & 4.57 & 0.12 \\
\hline 5 & 7.13 & -2.14 & 4.53 & 0.63 \\
\hline 69 & 73.2 & -2.13 & 4.53 & 0.63 \\
\hline 18 & 73.2 & -4.2 & 17.64 & 1.27 \\
\hline 13 & 10.9 & 2.1 & 4.41 & 0.40 \\
\hline 0 & 2.06 & -2.06 & 4.24 & 2.05 \\
\hline 145 & & & & 4.71 \\
\hline
\end{tabular}

\section{Calculated Value}

The calculated value is 4.71

Tabulated value:

Degree of freedom; (r-1) x (c-1)

$$
\begin{aligned}
& (2-1) \times(4-1) \\
& 1 \times 3=3
\end{aligned}
$$

The table value at $5 \%$ level is 7.815

Hence the calculated value 4.71 is less than the table value. $\mathrm{H}_{0}$ is accepted and $\mathrm{H}_{1}$ rejected.

\section{Inference:}

Hence there is no significant difference between gender and their willingness to take risk in investment decisions.

\section{Correlation Analysis}

Aim: To determine the relationship between the annual income and amount of investment in a year[14],[16], [18].

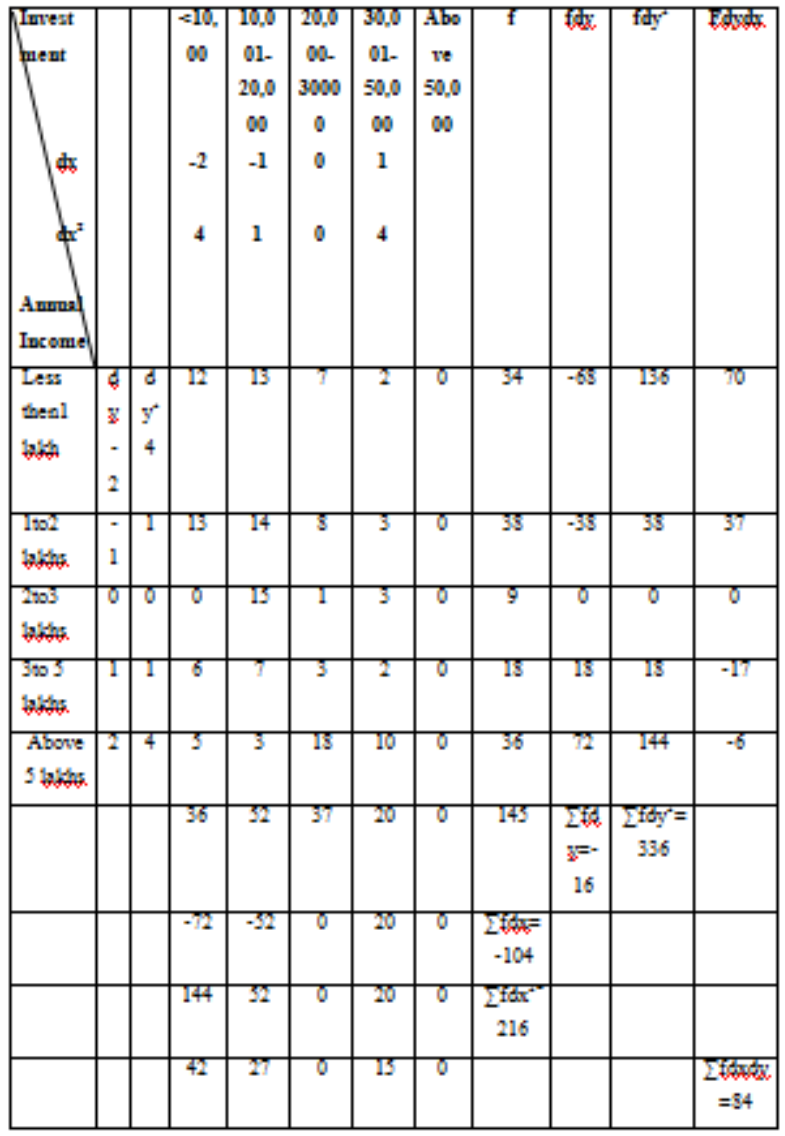

\section{Formula:}

$\mathrm{N} \sum \mathrm{fdxdy}-\sum \mathrm{fdx} * \sum \mathrm{fdy}$

$\mathrm{r}=$

$\sqrt{\mathrm{Nfdx}^{2}-\left(\sum \mathrm{fdx}\right)^{2} \sqrt{ } \mathrm{N} \sum \mathrm{fdy}^{2}-\left(\sum \mathrm{fdy}\right)^{2}}$ $145 * 84-(-104) *(-16)$

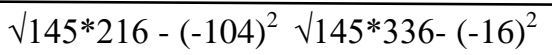

$12181-1664$

$\sqrt{ } 31320-10816 \sqrt{48720-256}$

10516

$\sqrt{ } 20504 \sqrt{ } 48464$

10516

$143.192 * 220145$

10516

$\mathrm{r}=+0.334$

$31,523.002$

Positively correlated

\section{Inference}

Though there exists a low positive correlation between the annual income and amount of investments of the investors, 
the lower stage maybe due to the depression in the financial market.

\section{RESULTS AND DISCUSSIONS}

The primary data has been collected from the selected investors, analyzed and various statistical tools have been used to test the reliability of the data. The following research findings are:

$\square 5$ per cent of investors have done schoolings, 8 per cent of investors have completed their diploma, 47 per cent of investors have done their degree, 37 per cent of investors have completed their post graduate degree and 3 per cent of investors have said others (M.Phil, Ph.D etc).

$\square$ From 145 investors, 21 per cent of investors have increase in value, 60 per cent of investors have income generation, 12 per cent of investors have liquidity, 5 per cent of investors have safety and 1 per cent of investors have others as their primary objectives for their investment in stocks.

$\square 17$ per cent of investors have less than one years, 28 per cent of investors have 1-3 years, 24 per cent of investors have 3-6 years and 31 per cent of investors have more than five years of investment experience[19],[21],[23].

41 per cent of investors hold their invested money for $<1$ years, 27 per cent of investors for 1-3 year, 19 per cent of investors for 3-6 year and 14 percent of investors for more than 6 year in long term investment.

$\square 18$ per cent of investors have very little, 22 per cent of investors have some what, 31 per cent of investors have moderate, 25 per cent of investors have good and 3 per cent of investors have extensive familiarity with investment strategies.

$\square$ 23,per cent of investors invest less than Rs. 10,000, 30 per cent of investors invest Rs. 10,001-20,000, 14 per cent of investors invest Rs.20,001-30000, 16 per cent of investors invest Rs.30,001-50,000, and 18 per cent of investors invest more than Rs.50,000 in a year.

$\square$ no investors said that they have high rate of return, 24 per cent of investors said that they have high rate of return, 56 per cent of investors said they have average rate of return and 20 per cent of investors said hey have low rate of return.

$\square$ no investors are willing to take very high level of risk, 31 per cent of investors are willing to take high of risk, 60 per cent of investors are willing to take average level of risk and 9 per cent of investors are willing to take low level of risk in taking investment decisions[20],[22],[24].

$\square 13$ per cent of investors expect less than $5 \%$ of total return, 19 per cent of investors expect 6-10\%, 23 per cent of investors expect $11-15 \%$ and 45 per cent of investors expect more than $15 \%$ of total return from their investment over long term.

$\square 35$ per cent of investors have the opinion that investment in stock market provide higher return, 25 per cent of investors have the opinion that in Derivatives, 18 percent of investors said from commodities, 10 per cent of investors said from Bank deposit, 10 per cent of investors said from mutual fund.

$\square 2$ per cent of investors are currently dealing with stocks, 5 per cent of investors are in derivatives segment, 23 per cent of investors in commodities, 18 per cent of investors in Bank deposit and 2 per cent of investors are currently dealing with mutual fund.

$\square 27$ per cent of investors have the stock markets investments are the safest form of yielding returns, 13 per cent of investors have the opinion as derivative investment, 10 per cent of investors commodities, 45 per cent of investors said as bank deposit and 5 per cent of investors have the opinion that mutual fund are the safest form of yielding returns.

$\square 38$ per cent of investors strongly agree that global financial crisis has eroded the investment value, 53 per cent of investors agree, 5 per cent of investors neither agree or disagree, 4 per cent of investors disagree and no investors strongly disagree that global financial crisis has eroded the investment value[25],[27],[29].

$\square 32$ per cent of investors strongly agree that investment in mutual fund is better option protect investment than in stock market , 45 per cent of investors agree, 17 per cent of investors neither agree or disagree, 6 per cent of investors disagree and no investors strongly disagree.

$\square 26$ per cent of investors were fully aware that the derivative segment can protect their investment in stock market, 44 per cent of investors said that they were partially aware and 35 per cent of investors said that they were not at all aware of derivative segment.

$\square$ There is significant difference between the opinion on safest form of yielding return on mutual fund are better option protect investment than stock market[26],[28],[30].

$\square$ Hence there is no significant difference between gender and their willingness to take risk in investment decisions.

$\square$ The exists a low positive correlation between the annual income and amount of investments of the investors, the lower stage maybe due to the depression in the financial market.

\section{CONCLUSION}

The investigation of this theme has uncovered different segments of the speculation and the sorts of speculator's frame of mind. With development of the financial conditions and recovery of the economic situations the financier firms will be in the situation to actualize the discoveries and the proposals. It would serve as the direction for the speculators as well as the business potential for the financier firm.

By far most of the money related masters are amazingly unstable about prosperity of their endeavor. They need more prosperity and faithful quality. Current example and basic access isn't affected the monetary authority as much as prosperity and enduring quality. Most of the obtaining people contribute their compensation up to different level in any division, so hypothesis association have also particularly degree of getting business[31],[33]. Worth market is moreover acclaimed among theorists on account of higher return, anyway in light of defenselessness and nonattendance of real learning money related experts don't place assets into that fragment. In any case, money related pros who have 
genuine data and availability to pull out all the stops up fairly are placing assets into Equity feature. Bank's advance expense is furthermore lessening since latest couple of years along these lines, examiners move towards various streets like shared save, security, esteem market and others like land, gold, constructing, etc. Along these lines, keep going end on part is that monetary masters of Yoha securities Ltd. are contributing their money with the equality of prosperity, steadfast quality and pace of return.

\section{REFERENCES}

1) BharthVajan R., Ramachandran S.,Psychographic dimensions of training,2016,International Journal of Pharmacy and Technology,V-8,I-4,P-23727-23729

2) Balakrishnan P., Bharthvajan R.,A study on human resource planning in hospitals in Chennai City,2014,International Journal of Applied Engineering Research,V-9,I-22,P-7503-7507

3) Priyadarsini P., Bharthvajan R.,Role of emotional intelligence training programme in reducing the stress of the nurses,2014,International Journal of Applied Engineering Research,V-9,I-22,P-7411-7421

4) Kerinab Beenu G., Bharthvajan R.,Empirical analysis on the cosmetic buying behavior of young women in South India,2014,International Journal of Applied Engineering Research,V-9,I-22,P-7361-7366

5) Balakrishnan P., Bharthvajan R.,Whistling in the wind,2014,International Journal of Applied Engineering Research,V-9,I-22,P-7586-7593

6) Krishnan B., Peter M.,Health hazards of Indian Bpo employee-an alarming issue,2014,International Journal of Applied Engineering Research,V-9,I-22,P-7336-7341

7) Kerinab Beenu G.H., Peter M.,Role of insurance in economic development,2014,International Journal of Applied Engineering Research,V-9,I-22,P-7532-7539

8) Balakrishnan P., Peter M., Priyadarsini P.,Efficiency of safety measures for wellbeing of employees in manufacturing industry,2014,International Journal of Applied Engineering Research,V-9,I-22,P-7376-7382

9) Anbarasi M., Praveen Kumar S.,Online sales promotions of herbal products and its effectiveness towards tanisha.com,2019,Indian Journal of Public Health Research and Development,V-10,I-1,P-195-200

10) Anbarasi M., Praveen Kumar S.,Various online marketing and promotions strategies to improve the validation towards the organic products in the pharmaceutical sectors,2019,Indian Journal of Public Health Research and Development, V-10,I-1,P-263-269

11) Loganathan R., Praveen Kumar S.,Grievance handling a key factor for solving issues of employees in an organization,2014,International Journal of Applied Engineering Research,V-9,I-22,P-7483-7491

12) Loganathan R., Praveen Kumar S.,Study on preference of private label brands in super and Hypermarkets,2014,International Journal of Applied Engineering Research,V-9,I-22,P-7327-7335

13) Smitha M., Praveen Kumar S.,Understanding stress and its managementamong the nurses in Chennai city,2014,International Journal of Applied Engineering Research,V-9,I-22,P-7560-7565

14) Kerinab Beenu G.H., Praveen Kumar S.,A study on the investment behavior of Chennai investors in mutual fund schemes,2014,International Journal of Applied Engineering Research,V-9,I-22,P-7520-7525

15) Loganathan R., Praveen Kumar S.,Retention strategies key for organizational productivity,2014,International Journal of Applied Engineering Research,V-9,I-22,P-7443-7447

16) Pavithra J., Ganesan M., Brindha G.,State wise analysis of microfinance sector in India,2016,International Journal of Pharmacy and Technology,V-8,I-4,P-23417-23432

17) Pavithra J., Ganesan M.,A comparative study on microfinance in India and abroad,2016,International Journal of Applied Business and Economic Research,V-14,I-8,P-5471-5476

18) Pavithra J., Ganesan M.,A study on awareness and impact of micro-financial schemes,2016,International Journal of Applied Business and Economic Research,V-14,I-8,P-5449-5460

19) Senthilmurugan P., Pavithra J.,Consumer preference towards organised retailing with reference to Big Bazaar,2014,International Journal of Applied Engineering Research,V-9,I-22,P-7469-7475

20) Senthilmurugan P., Pavithra J.,Implication of social media marketing in growing healthcare industry,2014,International Journal of Applied Engineering Research,V-9,I-22,P-7448-7456

21) Loganathan R., Pavithra J.,Consumer perception towards private label brand over other brands in super markets and hypermarkets,2014,International Journal of Applied Engineering Research,V-9,I-22,P-7355-7360
22) Kerinab Beenu G., Pavithra J.,Tradeâ€"off between liquidity and profitability in logistics industry,2014,International Journal of Applied Engineering Research,V-9,I-22,P-7398-7401

23) Kerinab Beenu G., Pavithra J.,A study on the prospective consumerâ $€^{\mathrm{TM}_{\mathrm{S}}}$ perception towards utility cars in Chennai city,2014,International Journal of Applied Engineering Research,V-9,I-22,P-7526-7531

24) Pavithra J., Dilli Babu P., Ambuli T.V.,A study on budgetary control at Maruti Service Masters, Chennai,2014,International Journal of Applied Business and Economic Research,V-12,I-2,P-151-161

25) Pavithra J., Dilli Babu P., Ambuli T.V.,A study on customer satisfaction of retro Garments Pvt Ltd, Chennai,2014,International Journal of Applied Business and Economic Research,V-12,I-2,P-381-391

26) Kerinab Beenu G.H., Pavithra J., Senthilmurugan P.,A study on the influence of promotional activities for TATA ARIA among consumers in Chennai,2014,International Journal of Applied Engineering Research,V-9,I-22,P-7572-7578

27) Vijayaragavan S.P.,An investigative expert that's general FBG sensors,International Journal of Mechanical Engineering and Technology,V-8,I-8,PP-1500-1505,Y-2017

28) Vijayaragavan S.P.,Equalization routing protocol for Wi-Fi sensor strategy,International Journal of Mechanical Engineering and Technology,V-8,I-8,PP-1662-1666,Y-2017

29) Karthik B., Kiran Kumar T.V.U., Vijayaragavan P., Bharath Kumaran E.,Design of a digital PLL using 0.35 $\hat{\mathrm{I}}^{1 / 4 \mathrm{~m}}$ CMOS technology,Middle East Journal of Scientific Research,V-18,I-12,PP-1803-1806,Y-2013

30) Kanniga E., Selvaramarathnam K., Sundararajan M.,Kandigital bike operating system,Middle - East Journal of Scientific Research,V

31) Jasmin M., Vigneshwaran T., Beulah Hemalatha S.,Design of power aware on chip embedded memory based FSM encoding in FPGA,International Journal of Applied Engineering Research,V-10,I-2,PP-4487-4496,Y-2015

32) Jasmin M.,Optimization techniques for low power VLSI circuits,Middle East Journal of Scientific Research,V-20,I-9,PP-1082-1087,Y-2014

33) Jasmin M., Vigneswaran T.,Fuzzy controller for error control of on - Chip communication,2017 International Conference on Algorithms, Methodology, Models and Applications in Emerging Technologies, ICAMMAET 2017,V-2017-January,I-,PP-1-5,Y-2017

\section{AUTHORS PROFILE}

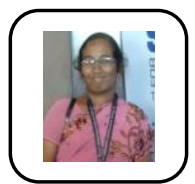

Ms. J Pavithra Assistant Professor, Department of MBA, Bharath Institute of Higher Education and Research, Chennai, India.

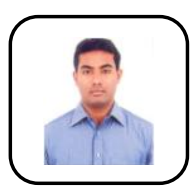

Anish.S Assistant Professor, Department of Civil Engineering, Bharath Institute of Higher Education and Research, Chennai, India.

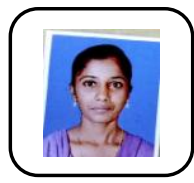

K. Premalatha Student, Department of MBA, Bharath Institute of Higher Education and Research, Chennai, India. 